\title{
Multiple Phenotypic Changes Define Neutrophil Priming
}

\author{
Irina Miralda ${ }^{1}$, Silvia M. Uriarte ${ }^{1,2}$ and Kenneth R. McLeish ${ }^{2,3 *}$ \\ ${ }^{1}$ Department of Microbiology, University of Louisville School of Medicine, Louisville, KY, United States, ${ }^{2}$ Department of \\ Medicine, University of Louisville School of Medicine, Louisville, KY, United States, ${ }^{3}$ Robley Rex VA Medical Center, Louisville, \\ $K Y$, United States
}

OPEN ACCESS

Edited by:

Joao Santana Silva,

University of São Paulo, Brazil

Reviewed by:

George Hajishengallis,

University of Pennsylvania,

United States

Henrique Serezani,

Vanderbilt University Medical Center,

United States

${ }^{*}$ Correspondence:

Kenneth R. McLeish

k.mcleish@/ouisville.edu

Received: 20 February 2017 Accepted: 11 May 2017 Published: 29 May 2017

Citation: Miralda I, Uriarte SM and McLeish KR (2017) Multiple Phenotypic Changes Define Neutrophil Priming. Front. Cell. Infect. Microbiol. 7:217. doi: 10.3389/fcimb.2017.00217
Exposure to pro-inflammatory cytokines, chemokines, mitochondrial contents, and bacterial and viral products induces neutrophils to transition from a basal state into a primed one, which is currently defined as an enhanced response to activating stimuli. Although, typically associated with enhanced generation of reactive oxygen species (ROS) by the NADPH oxidase, primed neutrophils show enhanced responsiveness of exocytosis, NET formation, and chemotaxis. Phenotypic changes associated with priming also include activation of a subset of functions, including adhesion, transcription, metabolism, and rate of apoptosis. This review summarizes the breadth of phenotypic changes associated with priming and reviews current knowledge of the molecular mechanisms behind those changes. We conclude that the current definition of priming is too restrictive. Priming represents a combination of enhanced responsiveness and activated functions that regulate both adaptive and innate immune responses.

Keywords: neutrophils, priming, cytokines, chemotaxis, apoptosis, phagocytosis, respiratory burst, exocytosis

\section{INTRODUCTION}

Polymorphonuclear leukocytes, or neutrophils, account for 40-60\% of peripheral blood leukocytes in humans (Summers et al., 2010). They play an essential role in the innate immune response, as demonstrated by the development of life-threatening infections or uncontrolled inflammation in individuals with severe neutropenia or genetic disruption of neutrophil anti-microbial capabilities (Kannengiesser et al., 2008; van de Vijver et al., 2012; Moutsopoulos et al., 2014; Nauseef and Borregaard, 2014). Figure 1 shows the multistep process of neutrophil recruitment in response to microbial invasion, including adhesion to vascular endothelium, transmigration into the interstitial space, chemotaxis/chemokinesis toward the site of infection, phagocytosis of pathogens, destruction of microbes within phagosomes by release of antimicrobial granule contents following granule fusion and ROS generation at the phagosomal membrane, and amplification and organization of the inflammatory response. Uncontrolled or prolonged neutrophil activation uses antimicrobial responses to injure normal host cells, leading to pathologic changes to tissues and organs in autoimmune and inflammatory diseases (Nathan, 2006). Consequently, neutrophil activation is normally tightly regulated.

Circulating neutrophils exist in a basal state, characterized by non-adherence, a round morphology, minimal transcriptional activity, and a limited capacity to respond to activating stimuli. That limited response protects against unwarranted inflammatory responses and tissue injury (Sheppard et al., 2005). To effectively clear invading organisms, neutrophils must be capable of mounting rapid, vigorous responses to activating stimuli. The transition to a state of enhanced 


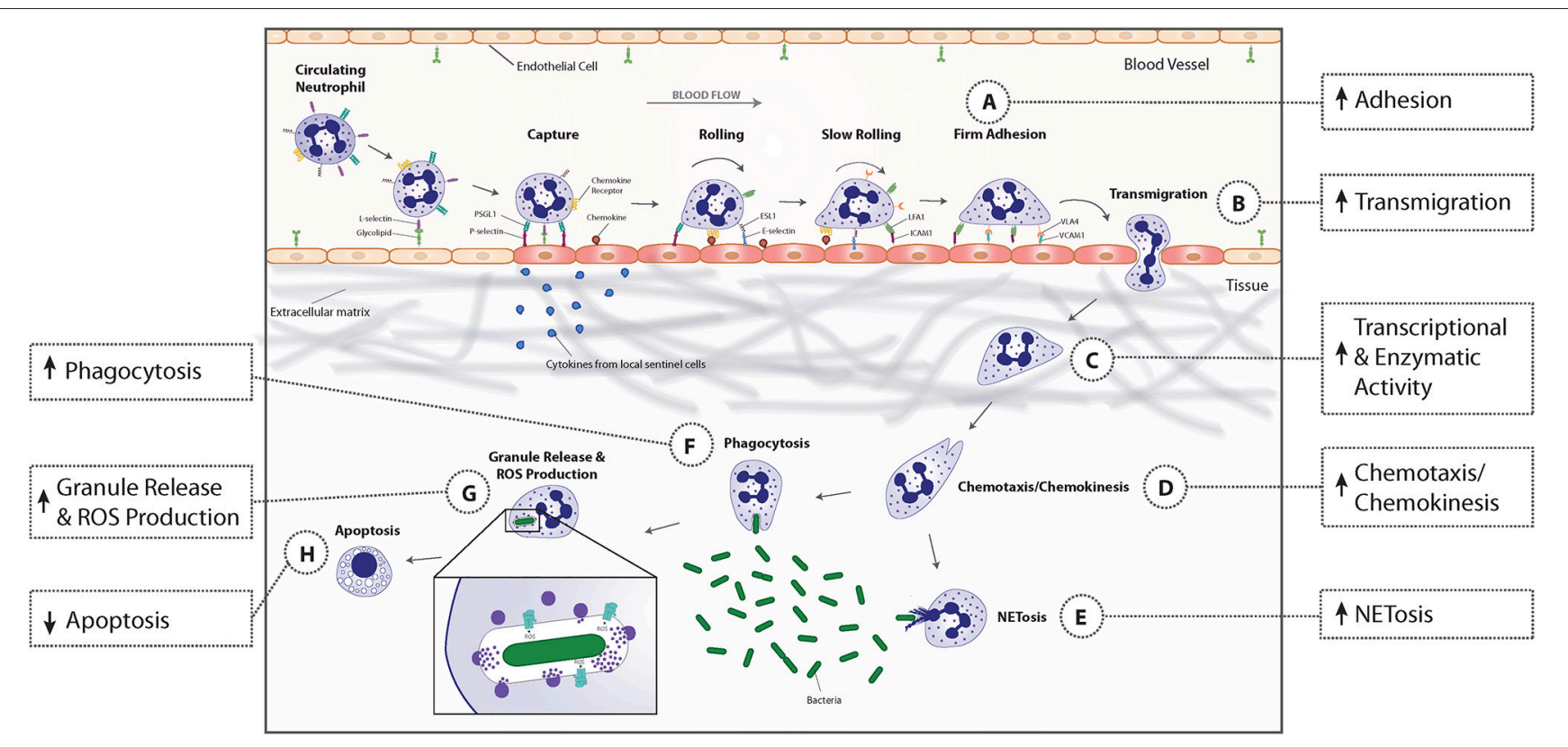

FIGURE 1 | Priming-associated phenotypic changes and their effect on neutrophil functional responses. Neutrophils in circulating blood are in a resting state, characterized by a round morphology, non-adherence, minimal transcriptional activity, and a limited capacity to respond to activating stimuli. Microbial entry into tissues or tissue injury induces local immune cells to release pro-inflammatory cytokines that modify endothelial cell adhesion molecule profile and enter the bloodstream to begin priming neutrophils. Upon exposure to these priming agents, neutrophils undergo an increase in enzymatic and transcriptional activity that results in activation and synthesis of inflammatory mediators and enzymes that mediate downstream phenotypic and functional changes. Immediately, neutrophils begin to change their adhesion receptor pattern by shedding selectins, fusing secretory vesicles with the plasma membrane which leads to increased integrin expression, and a rapid increase in the gene expression of several surface receptors that allows newly primed cells to more rapidly adhere to endothelial cells (A). This phenotypic change coupled with the release of granules containing matrix metalloproteases, promotes neutrophil migration into inflamed tissues (B). The priming process continues when neutrophils bind to extracellular matrix proteins (C). Binding of neutrophil extracellular matrix receptors leads to an increase in actin polymerization, available receptors from secretory vesicle degranulation, and intracellular signaling that results in enhanced chemotaxis and chemokinesis (D). When primed neutrophils encounter bacteria, their phagocytic capacity is increased due to the upregulation in the number and affinity of receptors on the plasma membrane (F). By then, ROS production, granule release (G), and NET formation (E) have been primed to augment microbicidal activities. Finally, priming prolongs neutrophil lifespan by activating anti-apoptotic signal transduction pathways and transcription factors that decrease transcription of pro-apoptotic factors $(\mathrm{H})$.

responsiveness has been termed priming (Condliffe et al., 1998; El-Benna et al., 2008; Wright et al., 2013). It occurs in vitro following neutrophil exposure to pro-inflammatory lipids and cytokines, chemokines, mitochondrial contents, and bacterial and viral products (El-Benna et al., 2008). Neutrophil priming in vitro represents an in vivo phenomena, as primed neutrophils have been identified in humans with infections, rheumatoid arthritis, chronic kidney disease, traumatic injury, and acute respiratory distress syndrome (Bass et al., 1986; McLeish et al., 1996; Ogura et al., 1999; Naegele et al., 2012). Although, substantial circumstantial evidence suggests that primed neutrophils participate in a number of human diseases, direct evidence is lacking. The relative contribution of neutrophil priming to the severity of human inflammatory diseases is an important gap in knowledge that needs to be addressed.

Historically, the term "priming" was primarily used to describe the augmented reactive oxygen species (ROS) generation upon neutrophil stimulation because of the depth of knowledge of molecular mechanisms of NADPH oxidase complex assembly, the ease of measurement of ROS generation, and the importance of ROS to anti-microbial activity. Figure 1 illustrates that primed neutrophils demonstrate a number of phenotypic changes in addition to enhanced NADPH oxidase activation, including granule release, cytokine and lipid synthesis, adhesion and transmigration, enhanced chemotaxis, and delayed apoptosis. Thus, neutrophil priming is not just a transition state in which neutrophils become more responsive to activating stimuli. We believe a new definition of priming is required to include the activation of a subset of neutrophil functions as opposed solely to a heightened state of responsiveness. In this review of the recent advances in neutrophil priming, we will highlight the functional evidence for the activation of a subset of neutrophil functions during priming and review the current state of knowledge of the molecular basis for those phenotypic changes to illustrate this new definition. Our goal is to encourage research that will provide a more complete understanding of priming, leading to identification of new targets for treatment of inflammatory and infectious diseases. Much of our discussion focuses on the effects of TNF $\alpha$, as studies frequently use that cytokine as a model priming agent. The large number of agents capable of initiating priming of neutrophil respiratory burst activity was recently reviewed (El-Benna et al., 2016). We compare current state of knowledge of the effects of 
those priming agents on the various phenotypic changes to those induced by TNF $\alpha$ in Table 1.

\section{PHENOTYPIC CHANGES DURING PRIMING}

\section{Respiratory Burst Activity}

For decades, enhanced respiratory burst activity has defined a primed neutrophil. The respiratory burst generates ROS through conversion of molecular oxygen to superoxide by the multi-component NADPH oxidase complex. The oxidase is comprised of three membrane subunits (gp91 $1^{\text {phox }} / \mathrm{NOX} 2$, p22 $2^{\text {phox }}$, and Rap1A) and four cytosolic proteins (p47 ${ }^{\text {phox }}$, p67 $7^{\text {phox }}, \mathrm{p} 40^{\text {phox }}$, and Rac2). Spatial separation of the membrane and cytosolic components maintains enzymatic inactivity in resting neutrophils. Upon stimulation, the cytosolic components translocate to the membrane to form the catalytically active enzyme complex. Phosphorylation of cytosolic NADPH oxidase components is necessary for translocation of those components to the plasma membrane. One of the major targets of phosphorylation is the $\mathrm{p}^{47^{\text {phox }}}$ subunit. Phosphorylation of a number of serines $\left(\mathrm{Ser}^{303}-\mathrm{Ser}^{379}\right.$ ) early in the activation process facilitates $\mathrm{p} 47^{\text {phox }}$ docking to membrane and cytosolic oxidase components, leading to assembly of the functional oxidase (El-Benna et al., 1994, 1996; Groemping et al., 2003).

Non-receptor tyrosine kinases and p38 mitogen-activated protein kinase (MAPK) are signaling molecules that participate in priming respiratory burst activity by $\mathrm{TNF} \alpha$ (El-Benna et al., 1996; McLeish et al., 1998; Forsberg et al., 2001; Dewas et al., 2003; Boussetta et al., 2010). Inhibition of tyrosine kinase activity blocks the activation of p38 MAPK by TNFa (McLeish et al., 1998), indicating that tyrosine kinases participate in priming by activating $\mathrm{p} 38 \mathrm{MAPK}$. TNF $\alpha$-mediated activation of the p38 MAPK pathway contributes to priming by enhancing plasma membrane translocation of the cytosolic components of the NADPH oxidase and by increasing expression of the plasma membrane oxidase components. Enhanced translocation of cytosolic components results from p38 MAPK-dependent phosphorylation of Ser ${ }^{345}$ on $\mathrm{p}^{4} 7^{\text {phox }}$. Phosphorylation of Ser $\mathrm{r}^{345}$ initiates a series of conformational changes in $\mathrm{p} 47^{\text {phox }}$ that result in hyperactivation of the NADPH oxidase. The initial event is binding of the prolyl isomerase Pin1 to the phospho-Ser ${ }^{345}$ site (Boussetta et al., 2010). This produces a conformational change in p4 $7^{\text {phox }}$ that exposes additional amino acids for phosphorylation by protein kinase C (PKC). Phosphorylation by PCK produces a second conformational change that promotes $\mathrm{p} 47^{\text {phox }}$ binding to $\mathrm{p} 22^{\text {phox }}$. That interaction leads to translocation and assembly of all the cytosolic oxidase components with the membrane NADPH oxidase components. Pin1 is also involved in priming by GM-CSF and CL097, a TLR8 agonist (Makni-Maalej et al., 2012, 2015). Unlike TNF $\alpha$, GM-CSF induces phosphorylation of $\mathrm{Ser}^{345}$ on $\mathrm{p}^{\text {phox }}$ through activation of ERK1/2, not $\mathrm{p} 38$ MAPK (Boussetta et al., 2010; Makni-Maalej et al., 2015). This observation indicates that multiple signal transduction pathways induce the same molecular events required for priming. Those redundant signal transduction pathways are unlikely to serve as effective therapeutic targets.

Over a decade ago, it was suggested that TNF $\alpha$ and LPS play a role in respiratory burst priming by influencing membrane trafficking (DeLeo et al., 1998; Ward et al., 2000). Direct confirmation was provided recently by selectively blocking exocytosis prior to priming through the use of cell-permeable, peptide inhibitors of SNARE protein interactions (Uriarte et al., 2011; McLeish et al., 2013). Those studies determined that exocytosis of secretory vesicles and gelatinase granules is required for priming by TNF $\alpha$ and platelet activating factor. Exocytosis could be contributing to priming by increasing plasma membrane expression of receptors, signaling molecules, and/or NADPH oxidase membrane components. The role of receptor and signaling molecule expression in priming was examined by measuring the activation of $\mathrm{p} 38$ MAPK and ERK1/2 in neutrophils primed during inhibition of exocytosis (Uriarte et al., 2011). The absence of granule exocytosis had no effect on activation of either MAPK, indicating that increased expression of receptors and signaling molecules does not contribute to priming (Uriarte et al., 2011). Inhibition of Pin 1 activity had no effect on neutrophil granule exocytosis (McLeish et al., 2013). We interpret those studies to indicate that enhanced translocation of cytosolic oxidase components and increased expression of membrane oxidase components are independent events, both of which are required for priming.

A second membrane trafficking event that participates in priming respiratory burst activity is clathrin-mediated endocytosis. Moreland and colleagues reported that the NADPH oxidase assembles on endosomes, and the subsequent $\mathrm{H}_{2} \mathrm{O}_{2}$ production was required for neutrophil priming by endotoxin (Moreland et al., 2007; Volk et al., 2011; Lamb et al., 2012). We have confirmed those observations and determined that endocytosis is an upstream event in neutrophil granule exocytosis.

\section{Neutrophil Granule Release}

Neutrophil granules are divided into four classes based on granule density and contents (Borregaard and Cowland, 1997; Lominadze et al., 2005; Rørvig et al., 2013). Secretory vesicles are created by endocytosis, while gelatinase (tertiary), specific (secondary), and azurophilic (primary) granules are formed from the trans-Golgi network during neutrophil maturation (Borregaard, 2010). Granule subsets undergo an ordered release based on stimulus intensity, termed graded exocytosis (Sengelov et al., 1993, 1995). Secretory vesicles undergo exocytosis more easily and completely than gelatinase granules. Specific and azurophilic granules, which contain toxic anti-microbial components, undergo the most limited exocytosis. An in vivo study showed that neutrophils migrating into a skin blister created in normal human subjects release nearly $100 \%$ of their secretory vesicles, $40 \%$ of gelatinase granules, $20 \%$ of specific granules, and $<10 \%$ of azurophilic granules (Sengelov et al., 1995).

We recently reported that TNF $\alpha$ directly stimulated exocytosis of secretory vesicles and gelatinase granules (McLeish et al., 2017). Those results support previous studies showing that 

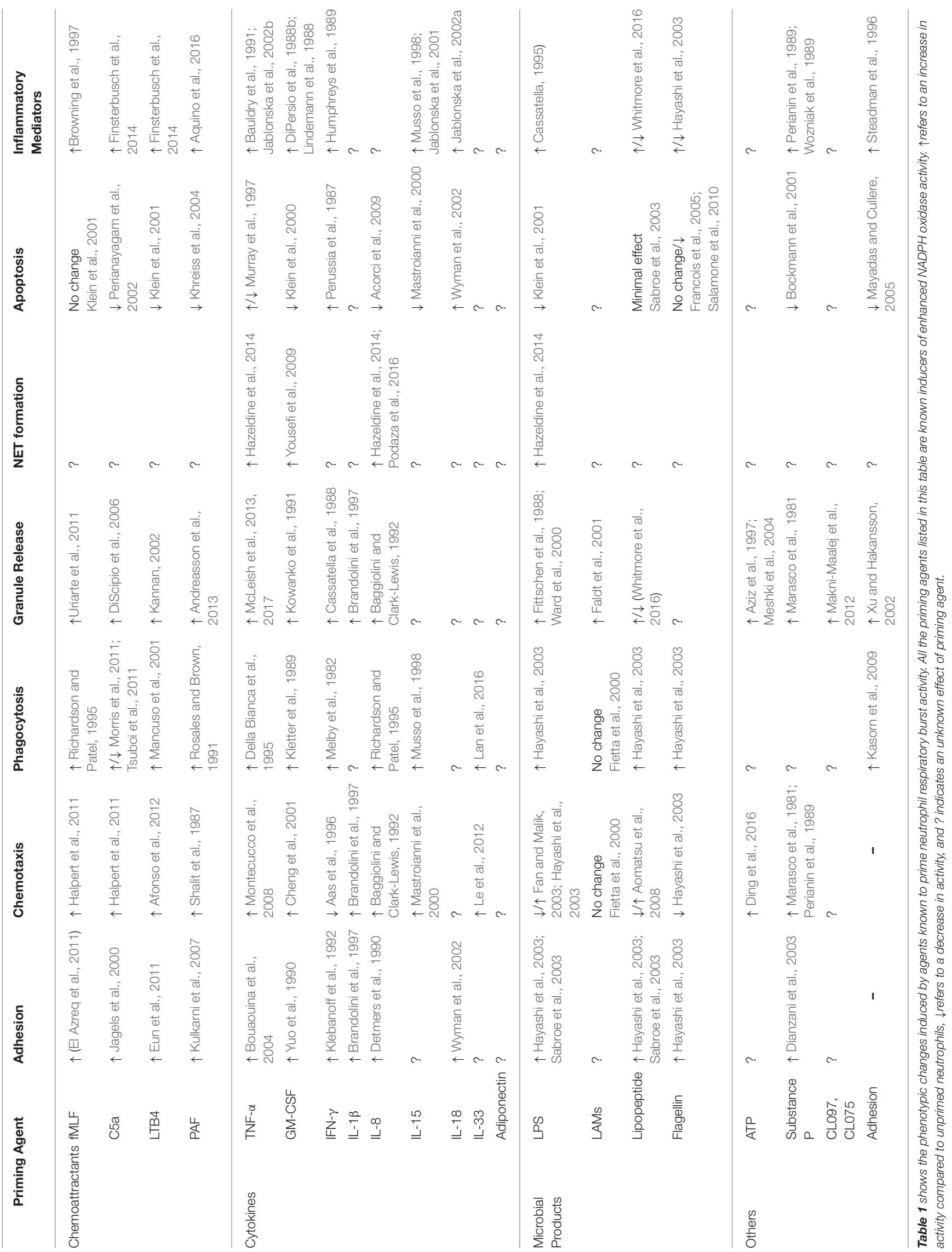

than 
exocytosis of secretory vesicles and gelatinase granule is required for $\mathrm{TNF} \alpha$-induced priming (McLeish et al., 2013). Neither $\mathrm{TNF} \alpha$ nor fMLF, alone, stimulated exocytosis of specific and azurophilic granules. However, $\mathrm{TNF} \alpha$ primed the release of both granule subsets upon subsequent stimulation by fMLF (McLeish et al., 2017). The ability of TNF $\alpha$ to prime exocytosis of azurophilic granules was also reported by Potera et al. (2016). Thus, differential regulation of exocytosis of the four granule subsets by TNF $\alpha$ primes the two major neutrophil antimicrobial defense mechanisms for enhanced release of ROS and toxic granule contents, while protecting against cell injury from inappropriate release of those toxic products. On the other hand, Ramadass et al. showed that GM-CSF both stimulated and primed exocytosis of gelatinase, specific, and azurophilic granules in mouse neutrophils (Ramadass et al., 2017). The basis for differences between TNF $\alpha$ and GM-CSF could be due to disparate capabilities of priming agents or to species differences.

Proteins that control priming by regulating exocytosis have only recently been identified. As pharmacologic inhibition of p38 MAPK prevents TNF- $\alpha$ stimulated exocytosis (Mocsai et al., 1999; Uriarte et al., 2011; McLeish et al., 2013), we employed a phosphoproteomic analysis by mass spectrometry to identify proteins phosphorylated by the p38 MAPK pathway during TNF $\alpha$ stimulation (McLeish et al., 2017). Four of the proteins identified, Raf1, MARCKS, ABI1, and myosin VI, were previously shown to be involved in exocytosis in various cells. We confirmed that Raf1 participates in TNF $\alpha$-stimulated exocytosis. Catz and colleagues used neutrophils from transgenic mice to identify Rab27a and its target, Munc13-4, as mediators of neutrophil exocytosis stimulated by GM-CSF (Ramadass et al., 2017). They showed that Rab27a, but not Munc13-4, was required for GMCSF priming of exocytosis to subsequent stimulation by TLR agonists or formyl peptides. Thus, the mechanisms that control neutrophil exocytosis during priming offer potential targets for intervention in inflammatory processes in which neutrophil priming is involved.

\section{Adhesion, Chemotaxis, and Phagocytosis}

As shown in Figure 1, microbial invasion or tissue injury releases pathogen-associated molecular pattern (PAMPs) or damageassociated molecular pattern (DAMPs) molecules that induce sentinel immune cells to release pro-inflammatory cytokines. Those cytokines modify both endothelial cell and neutrophil adhesion molecule expression to facilitate the capture of circulating neutrophils and to mediate their migration into tissues. As shown in Table 1, all priming agents for which there are data directly activate neutrophil adhesion. However, differential regulation of adhesion molecule expression and activation by different priming agents may produce different rates of neutrophil adhesion and migration efficiency. For example, neutrophil exposure to $\mathrm{TNF} \alpha$ increases plasma membrane expression of the $\beta 2$ integrin receptor, CD11b/CD18, through exocytosis of secretory vesicles; decreases expression of the selectin receptor $\mathrm{CD} 62-\mathrm{L}$ through receptor shedding; and induces sustained activation of CD11b/CD18 through inside-out signaling (Condliffe et al., 1996; Swain et al., 2002). On the other hand, PAF increases surface expression of the CD11b/CD18, has no effect on selectin expression, and induces only transient activation of CD11b/CD18 (Berends et al., 1997; Khreiss et al., 2004). The in vivo significance of those differences in adhesion molecule expression and activation remains to be determined.

With the exception of IFN $\gamma$, neutrophil chemotaxis is enhanced by all priming agents for which there are data (Table 1). In addition to increased expression of adhesion molecules and receptors resulting from exocytosis, priming agents increase actin reorganization (Borgquist et al., 2002), and enhances chemokinesis and chemotaxis (Montecucco et al., 2008; Yao et al., 2015). For example, treatment of neutrophils with PAF, IL-8, or TNF $\alpha$, alone, induces chemokinesis, while subsequent exposure to an fMLF gradient leads to enhanced neutrophil chemotaxis (Drost and MacNee, 2002). Additionally, TNF $\alpha$ primed neutrophils gain the ability to migrate toward the chemokine CCL3, which is found in inflammatory sites, but is normally not a neutrophil chemo attractant (Montecucco et al., 2008).

Neutrophil adhesion through both the engagement of neutrophil $\beta 2$ integrin receptors with endothelial cell adhesion molecules and the binding of neutrophil receptors with extracellular matrix proteins primes respiratory burst activity (Stanislawski et al., 1990; Dapino et al., 1993; Liles et al., 1995). Neutrophil adhesion induces other priming phenotypes, including exocytosis of secretory vesicles and gelatinase granules and a reduced rate of apoptosis (Hu et al., 2004; McGettrick et al., 2006; Paulsson et al., 2010). Thus, transmigration of neutrophils into the extravascular space can be expected to directly induce some of the features of priming.

When neutrophils arrive at the site of infection, they demonstrate increased phagocytosis due to upregulation in the number and affinity of phagocytic receptors (Condliffe et al., 1998; Rainard et al., 2000; Le et al., 2012). Table 1 lists the effects of specific priming agents on phagocytosis. Exposure of bovine neutrophils to the combination of two priming agents, $\mathrm{TNF} \alpha$ and C5a each at suboptimal concentrations, enhanced both the rate of phagocytosis and the killing capacity toward serum opsonized Staphylococcus aureus (Rainard et al., 2000); and incubation of human neutrophils with insulin-like growth factor I (IGF-I) results in a significant increase in phagocytosis of both IgG-opsonized S. aureus and serum-opsonized Candida albicans (Bjerknes and Aarskog, 1995). Increased neutrophil phagocytosis is dependent on the concentration and incubation time with IGF-1, and is due to increased complement receptor (CR) 1 and CR3 expression. IGF-1 enhances Fc $\gamma$ receptordependent phagocytosis through increased receptor function and activation, while Fc $\gamma$ receptor expression is unchanged (Bjerknes and Aarskog, 1995). Thus, neutrophil exposure to the complex milieu of priming agents in vivo is likely to produce additive or synergistic changes in functional responses. Defining neutrophil responses in that complex environment will require application of systems biology methodologies.

\section{Neutrophil Extracellular Trap (NET) Formation}

Since their first description in 2004, neutrophil extracellular traps (NETs) have received intense investigation. Although, the 
majority of studies have measured NET formation by resting neutrophils, neutrophils from normal subjects primed by TNF $\alpha$ in vitro demonstrated robust NET formation following a $3 \mathrm{~h}$ exposure to anti-neutrophil cytoplasmic antibodies (Kessenbrock et al., 2009). Enhanced NET formation in primed neutrophils is supported by other in vitro studies using GM-CSF and TNF $\alpha$ (Yousefi et al., 2009; Hazeldine et al., 2014). The effect of priming agents on NET formation is listed in Table $\mathbf{1}$.

Despite their original classification as the third bacterial killing mechanism, current opinion leans toward NETs being important contributors to autoimmunity and tissue injury, rather than antibacterial activity (Sorensen and Borregaard, 2016). In vivo, enhanced NET formation following a systemic change in levels of inflammatory cytokines has been described in cancers, multiple sclerosis, and diabetes (Chechlinska et al., 2010; Naegele et al., 2012; Fadini et al., 2016). Using a chronic myelogenous leukemia mouse model, Demers and colleagues reported that non-malignant neutrophils showed enhanced NET formation, leading to increased coagulation and thrombosis (Demers et al., 2012). Priming of NET formation was reproduced in control mice by sequential administration of granulocyte colonystimulating factor (G-CSF) and LPS. The authors suggested that priming NET formation by systemic cytokines plays a role in cancer progression. While the current literature indicates that enhanced NET formation is a component of neutrophil priming, the functional consequences of that response remain to be determined.

\section{Secretion of Lipid and Cytokine Mediators}

As summarized in Table 1, primed neutrophils demonstrate increased metabolic and transcriptional activity that leads to synthesis of a number of pro- and anti-inflammatory chemokines, cytokines, and lipids. Although, the ability of neutrophils to synthesize those products is less than that of macrophages, the large number of neutrophils present at sites of inflammation is postulated to influence both innate and adaptive immune responses through release of those inflammatory mediators.

Pro-inflammatory lipid mediators like leukotriene $\mathrm{B}_{4}\left(\mathrm{LTB}_{4}\right)$ can be produced de novo by the arachidonate 5-lipoxygenase (5-LO) pathway in neutrophils and play important roles in aggregation, degranulation, and chemotaxis (O'Flaherty et al., 1979; Flamand et al., 2000). The production of these lipid mediators occurs through a series of biochemical events that primarily take place in the perinuclear region where membrane phospholipids are first converted to arachidonic acid (AA) by the calcium-dependent enzyme phospholipase A2 (PLA $)$ (Luo et al., 2003; Leslie, 2004). The newly synthesized AA is then converted by 5 -LO into leukotriene $\mathrm{A}_{4}\left(\mathrm{LTA}_{4}\right)$, which is the immediate precursor of $\mathrm{LTB}_{4}$. Neutrophil production of LTB4 is responsible for a second wave of neutrophil recruitment during inflammation, a process termed "swarming" (Lammermann et al., 2013). This is one of many examples of amplification loops initiated by neutrophils (Nemeth and Mocsai, 2016).

Direct activation of neutrophils by fMLF does not lead to the detectable release of leukotrienes, but priming with GMCSF, LPS, or TNF $\alpha$ followed by fMLF stimulation significantly increases $\mathrm{LTB}_{4}$ release (see Table 1; DiPersio et al., 1988a; Schatz-Munding and Ullrich, 1992; Palmantier et al., 1994; Seeds et al., 1998; Zarini et al., 2006). All three of these priming agents activate $\mathrm{PLA}_{2}$ and increase AA release without increasing intracellular $\mathrm{Ca}^{2+}$ (DiPersio et al., 1988b; Schatz-Munding and Ullrich, 1992; Zarini et al., 2006). The elevation in available AA substrate leads to prolonged activation of 5-LO and enhanced production of downstream lipid mediators (Surette et al., 1993, 1998; Doerfler et al., 1994). Once produced, $\mathrm{LTB}_{4}$ can exert autocrine effects. It primes neutrophil responses to toll-likereceptor (TLR) agonists, resulting in enhanced cytokine (IL-8, $\mathrm{TNF} \alpha$ ) secretion (Gaudreault et al., 2012). TLR9 mRNA levels are upregulated upon priming with $\mathrm{LTB}_{4}$, but there is no increase in surface expression of TLR2, TLR4, or the co-receptors TLR1 and TLR6 following $\mathrm{LTB}_{4}$ exposure (Gaudreault and Gosselin, 2009; Gaudreault et al., 2012). Instead, neutrophil $\mathrm{LTB}_{4}$ induced hyper-responsiveness is mediated by the potentiation of TLR-induced intracellular signaling. TAK1 and p38 MAPK, which are essential in TLR-activated cytokine release, are phosphorylated and activated following $\mathrm{LTB}_{4}$ interaction with its seven transmembrane-spanning receptor.

PAF is another lipid inflammatory mediator whose production is primed in neutrophils. Both LPS and GMCSF enhance PAF synthesis in response to activating stimuli (Aglietta et al., 1990; Surette et al., 1998). After priming with GMCSF, there is increased enzymatic activity of acetyl transferase, the enzyme responsible for the synthesis of PAF (Aglietta et al., 1990). However, the pattern of PAF synthesis after LPS priming is attributed to a biphasic, autocrine response. The early peak in production is due to the direct effect of LPS, while the delayed peak is a result of LPS-induced IL- 8 and TNF- $\alpha$ release (Bussolati et al., 1997).

Neutrophils modulate inflammation through the release of stored or newly produced cytokines and chemokines (Cassatella, 1999). Exposure of neutrophils to priming agents leads to an increase in synthesis and release of IL- $1 \alpha$, IL-1 $\beta$, IL-6, IL8, TNF $\alpha$, CXCL1, CXCL2, CCL3 (MIP-1 $\alpha$ ), CCL4 (MIP-1 $\beta$ ) (Roberge et al., 1998; Zallen et al., 1999; Jablonska et al., 2002b; Choi et al., 2008; Wright et al., 2013). The inducible synthesis of the majority of cytokines and chemokines results from increased gene transcription (Marucha et al., 1991; Cassatella et al., 1995; Cassatella, 1996, 1999; Fernandez et al., 1996). TNFa, LPS, and GM-CSF increase intra-nuclear translocation of NF- $\kappa \mathrm{B}, \mathrm{C} / \mathrm{EBP}$, or CREB transcription factors (Cloutier et al., 2007, 2009; Mayer et al., 2013). LPS induces a biphasic production of IL-8. For the first few hours (2-6 h) of exposure, LPS directly stimulates IL-8 synthesis, but the second wave of sustained IL- 8 release (up to 18 $\mathrm{h}$ ) is due to the endogenous release of TNF $\alpha$ and IL-1 $\beta$ (Cassatella et al., 1993).

\section{Release of Neutrophil Extracellular Vesicles}

Cell-derived vesicles represent a mechanism for cell-cell communication. Exosomes are 50-100 nm vesicles released from multivesicular bodies that are involved in antigen presentation and cell-to-cell transfer of receptors or RNA (Gyorgy et al., 
2011). Larger vesicles, called microvesicles or microparticles express tissue factors on their surface that are capable of initiating coagulation. Neutrophils undergoing apoptosis or stimulated by chemotactic agents, opsonic receptors, or TNF $\alpha$ release microparticles. However, the microparticles have varying compositions and functional capabilities, depending on the stimulus (Dalli et al., 2013; Johnson et al., 2014; Lorincz et al., 2015). Microparticles obtained from neutrophils stimulated by chemotactic agents or phorbol esters activate cytokine (IL6) secretion from endothelial cells and platelets (Mesri and Altieri, 1998; Pluskota et al., 2008). Chemotactic peptide-induced microparticles increase secretion of the anti-inflammatory cytokine transforming growth factor- $\beta$ and interfere with the maturation of monocyte-derived dendritic cells (Gasser and Schifferli, 2004; Eken et al., 2010). Auto-antibody-stimulated release of neutrophil microparticles was suggested to be involved in the pathogenesis of vasculitis (Hong et al., 2012). Additional activities ascribed to neutrophil microparticles include suppression of bacterial growth, activation of endothelial cell cytokine production, altered cytokine profile of natural killer cells and monocytes, and increased coagulation (Mesri and Altieri, 1998; Timar et al., 2013a,b; Pliyev et al., 2014). An understanding of the stimuli and signal transduction pathways leading to formation and release of neutrophil extracellular vesicles and their roles in inflammation remains to be developed.

\section{Rate of Apoptosis}

Table $\mathbf{1}$ indicates that neutrophil apoptosis is variably affected in response to priming agents. While LPS, GM-CSF, IL-8, and $\mathrm{LTB}_{4}$ have been found to extend neutrophil lifespan in vitro, PAF, fMLF, and IL- 6 show no effect, and TNF $\alpha$ shows a biphasic response where it promotes apoptosis during the first $8 \mathrm{~h}$ of exposure, followed by a delayed rate of apoptosis at later times (Klein et al., 2000, 2001; Cowburn et al., 2002; Liu et al., 2005; Wright et al., 2014). Primed neutrophils from patients with multiple sclerosis, ANCA-associated vasculitis, and liver cirrhosis show increased apoptosis (Harper et al., 2001; Klimchenko et al., 2011; Naegele et al., 2012), while neutrophils from patients at risk of multiple-organ failure and individuals presenting with septic peritonitis, severe trauma, or septic trauma show a decrease in apoptosis (Ertel et al., 1998; Biffl et al., 1999, 2001; Nolan et al., 2000; Feterowski et al., 2001). Those conflicting reports of the effect of inflammation on apoptosis in vivo are likely due to different priming agents involved in different diseases, different responses during the time course of disease, and differences in the neutrophil micro-environment, such as cell density (Hannah et al., 1998).

The mechanisms underlying the effects of priming on neutrophil apoptosis have been partially characterized. As for $\mathrm{TNF} \alpha$, increased rates of apoptosis during the first hours of exposure are associated with activation of caspase cascades (Murray et al., 1997). TNFo also induces an early, PI-3Kmediated increase in mRNA levels for Bad, a member of the BCL2 family that regulates apoptosis. On the other hand, decreased neutrophil apoptosis observed at later time points is associated with a reduction in Bad mRNA levels (Cowburn et al., 2002). GM-CSF, IL-8, LPS, and $\mathrm{LTB}_{4}$ decrease the rate of neutrophil apoptosis through activation of ERK1/2 and/or PI-3K/Akt pathways (Klein et al., 2000, 2001). Incubation of neutrophils with $\mathrm{PLLF}$ had no effect on the rate of apoptosis, despite activation of both ERK1/2 and Akt (Klein et al., 2001). GM-CSF was also shown to decrease mRNA levels of Bad, while increasing its phosphorylation (Cowburn et al., 2002). A RNA seq study comparing TNF $\alpha$ and GM-CSF priming pathways showed that out of 580 genes differentially expressed between both agents, 58 were implicated in the delay of apoptosis. Thus, each priming agent produced a distinct profile of pro- and anti-apoptotic genes (Wright et al., 2013). The varying rates of neutrophil apoptosis may serve different functions in the inflammatory response. For example, a reduced rate of apoptosis early in the recruitment of neutrophils results in a brisk accumulation of primed neutrophils. On the other hand, an enhanced rate of apoptosis at later time points promotes resolution through loss of active neutrophils and a change in phenotype of monocytes engulfing apoptotic neutrophils.

\section{CONCLUSIONS}

The altered neutrophil functions described in this review indicate that priming is a complex phenomenon. Priming involves enhanced respiratory burst, exocytosis, NET formation, and chemotaxis in response to a second stimulus. Priming, however, is not just preparation for an enhanced response to a second stimulus. Priming involves activation of a subset of neutrophil responses, including adhesion, transcription, cytoskeletal reorganization, translocation and expression of receptors, and other molecules, the rate of constitutive apoptosis, metabolic activity, and phagocytosis. The altered neutrophil responses associated with priming primarily result in amplification of the inflammatory response. Although, recruitment of primed neutrophils improves the clearance of invading microbes, the risk of directly injuring surrounding cells is increased. Moreover, the increased synthesis and release of cytokines and lipids by primed neutrophils, combined with increased neutrophil recruitment and life-span, result in an increased local concentration of pro-inflammatory agents. Those agents recruit and prime additional neutrophils, leading to an enhanced innate immune response. Neutrophildependent recruitment and activation of dendritic cells and various lymphocyte subsets also enhances the adaptive immune response.

We propose that the current definition of priming, which focuses on a transition state to an enhanced responsiveness to a second stimulus, is too restrictive. Neutrophil priming also results in activation of a subset of neutrophil responses that regulate innate and adaptive immunity. Additionally, neutrophil responses to priming agents vary depending on concentration of the priming agent, time of exposure, and the specific priming agent (Potera et al., 2016; McLeish et al., 2017). It seems likely that neutrophils are exposed to graded concentrations of priming agents as they progress through the multistep process of recruitment, as occurs with chemoattactants. This leads to the hypothesis that, similar to graded granule exocytosis, priming 
occurs in a graded manner during a neutrophil's journey to the site of inflammation. This graded response allows neutrophils to acquire functions in an ordered manner, as required during recruitment. A fully primed neutrophil that releases a maximal amount of toxic chemicals would occur when an optimal concentration of a priming stimulus is encountered. Combining knowledge of the molecular events with an understanding of priming at a systems level will identify therapeutic targets for neutrophil functions that exacerbate individual diseases, while preserving the functions that participation in host defense.

\section{REFERENCES}

Aas, V., Lappegard, K. T., Siebke, E. M., and Benestad, H. B. (1996). Modulation by interferons of human neutrophilic granulocyte migration. J. Interferon Cytokine Res. 16, 929-935. doi: 10.1089/jir.1996.16.929

Acorci, M. J., Dias-Melicio, L. A., Golim, M. A., Bordon-Graciani, A. P., Peracoli, M. T., and Soares, A. M. (2009). Inhibition of human neutrophil apoptosis by Paracoccidioides brasiliensis: role of interleukin-8. Scand. J. Immunol. 69, 73-79. doi: 10.1111/j.1365-3083.2008.02199.x

Afonso, P. V., Janka-Junttila, M., Lee, Y. J., McCann, C. P., Oliver, C. M., Aamer, K. A., et al. (2012). LTB4 is a signal-relay molecule during neutrophil chemotaxis. Dev. Cell 22, 1079-1091. doi: 10.1016/j.devcel.2012.02.003

Aglietta, M., Monzeglio, C., Apra, F., Mossetti, C., Stern, A. C., Giribaldi, G., et al. (1990). In vivo priming of human normal neutrophils by granulocyte-macrophage colony stimulating factor: effect on the production of platelet activating factor. Br. J. Haematol. 75, 333-339. doi: 10.1111/j.1365-2141.1990.tb04345.x

Andreasson, E., Onnheim, K., and Forsman, H. (2013). The subcellular localization of the receptor for platelet-activating factor in neutrophils affects signaling and activation characteristics. Clin. Dev. Immunol. 2013:456407. doi: $10.1155 / 2013 / 456407$

Aomatsu, K., Kato, T., Fujita, H., Hato, F., Oshitani, N., Kamata, N., et al. (2008). Toll-like receptor agonists stimulate human neutrophil migration via activation of mitogen-activated protein kinases. Immunology 123, 171-180. doi: 10.1111/j.1365-2567.2007.02684.x

Aquino, E. N., Neves, A. C., Santos, K. C., Uribe, C. E., Souza, P. E., Correa, J. R., et al. (2016). Proteomic analysis of neutrophil priming by PAF. Protein Pept. Lett. 23, 142-151. doi: 10.2174/0929866523666151202210604

Aziz, K. A., Cawley, J. C., Treweeke, A. T., and Zuzel, M. (1997). Sequential potentiation and inhibition of PMN reactivity by maximally stimulated platelets. J. Leukoc. Biol. 61, 322-328.

Baggiolini, M., and Clark-Lewis, I. (1992). Interleukin-8, a chemotactic and inflammatory cytokine. FEBS Lett. 307, 97-101. doi: 10.1016/0014-5793(92)80909-Z

Bass, D. A., Olbrantz, P., Szejda, P., Seeds, M. C., and McCall, C. E. (1986). Subpopulations of neutrophils with increased oxidative product formation in blood of patients with infection. J. Immunol. 136, 860-866.

Bauldry, S. A., McCall, C. E., Cousart, S. L., and Bass, D. A. (1991). Tumor necrosis factor-alpha priming of phospholipase A2 activation in human neutrophils. An alternative mechanism of priming. J. Immunol. 146, 1277-1285.

Berends, C., Dijkhuizen, B., de Monchy, J. G., Dubois, A. E., Gerritsen, J., and Kauffman, H. F. (1997). Inhibition of PAF-induced expression of CD11b and shedding of L-selectin on human neutrophils and eosinophils by the type IV selective PDE inhibitor, rolipram. Eur. Respir. J. 10, 1000-1007. doi: 10.1183/09031936.97.10051000

Biffl, W. L., Moore, E. E., Zallen, G., Johnson, J. L., Gabriel, J., Offner, P. J., et al. (1999). Neutrophils are primed for cytotoxicity and resist apoptosis in injured patients at risk for multiple organ failure. Surgery 126, 198-202. doi: 10.1016/S0039-6060(99)70155-8

Biffl, W. L., West, K. E., Moore, E. E., Gonzalez, R. J., Carnaggio, R., Offner, P. J., et al. (2001). Neutrophil apoptosis is delayed by trauma patients' plasma via

\section{AUTHOR CONTRIBUTIONS}

Contributed to the writing and editing of the manuscript IM, $\mathrm{KM}$, SU; designed and illustrated the figure IM.

\section{FUNDING}

The authors were supported by a Merit Review Award (BX001838) from the Department of Veterans Affairs (KM) and by the National Institute of Dental and Craniofacial Research (DE024509 to SU). a mechanism involving proinflammatory phospholipids and protein kinase C. Surg. Infect. 2, 289-293; discussion: 294-285. doi: 10.1089/10962960152813322 Bjerknes, R., and Aarskog, D. (1995). Priming of human polymorphonuclear neutrophilic leukocytes by insulin-like growth factor I: increased phagocytic capacity, complement receptor expression, degranulation, and oxidative burst. J. Clin. Endocrinol. Metab. 80, 1948-1955.

Bockmann, S., Seep, J., and Jonas, L. (2001). Delay of neutrophil apoptosis by the neuropeptide substance P: involvement of caspase cascade. Peptides 22, 661-670. doi: 10.1016/S0196-9781(01)00376-X

Borgquist, J. D., Quinn, M. T., and Swain, S. D. (2002). Adhesion to extracellular matrix proteins modulates bovine neutrophil responses to inflammatory mediators. J. Leukoc. Biol. 71, 764-774.

Borregaard, N. (2010). Neutrophils, from marrow to microbes. Immunity 33, 657-670. doi: 10.1016/j.immuni.2010.11.011

Borregaard, N., and Cowland, J. B. (1997). Granules of the human neutrophilic polymorphonuclear leukocyte. Blood 89, 3503-3521.

Bouaouina, M., Blouin, E., Halbwachs-Mecarelli, L., Lesavre, P., and Rieu, P. (2004). TNF-induced beta2 integrin activation involves Src kinases and a redox-regulated activation of p38 MAPK. J. Immunol. 173, 1313-1320. doi: 10.4049/jimmunol.173.2.1313

Boussetta, T., Gougerot-Pocidalo, M. A., Hayem, G., Ciappelloni, S., Raad, H., Arabi Derkawi, R., et al. (2010). The prolyl isomerase Pin1 acts as a novel molecular switch for TNF-alpha-induced priming of the NADPH oxidase in human neutrophils. Blood 116, 5795-5802. doi: 10.1182/blood-2010-03-273094

Brandolini, L., Sergi, R., Caselli, G., Boraschi, D., Locati, M., Sozzani, S., et al. (1997). Interleukin-1 beta primes interleukin-8-stimulated chemotaxis and elastase release in human neutrophils via its type I receptor. Eur. Cytokine Netw. 8, 173-178.

Browning, D. D., Pan, Z. K., Prossnitz, E. R., and Ye, R. D. (1997). Cell type- and developmental stage-specific activation of NF-kappaB by fMet-LeuPhe in myeloid cells. J. Biol. Chem. 272, 7995-8001. doi: 10.1074/jbc.272. 12.7995

Bussolati, B., Mariano, F., Montrucchio, G., Piccoli, G., and Camussi, G. (1997). Modulatory effect of interleukin-10 on the production of platelet-activating factor and superoxide anions by human leucocytes. Immunology 90, 440-447. doi: 10.1111/j.1365-2567.1997.00440.x

Cassatella, M. A. (1995). The production of cytokines by polymorphonuclear neutrophils. Immunol. Today 16, 21-26. doi: 10.1016/0167-5699(95)80066-2

Cassatella, M. A. (1996). Interferon-gamma inhibits the lipopolysaccharideinduced macrophage inflammatory protein-1 alpha gene transcription in human neutrophils. Immunol. Lett. 49, 79-82. doi: $10.1016 / 0165-2478(95) 02484-0$

Cassatella, M. A. (1999). Neutrophil-derived proteins: selling cytokines by the pound. Adv. Immunol. 73, 369-509. doi: 10.1016/S0065-2776(08)60791-9

Cassatella, M. A., Cappelli, R., Della Bianca, V., Grzeskowiak, M., Dusi, S., and Berton, G. (1988). Interferon-gamma activates human neutrophil oxygen metabolism and exocytosis. Immunology 63, 499-506.

Cassatella, M. A., Gasperini, S., Calzetti, F., McDonald, P. P., and Trinchieri, G. (1995). Lipopolysaccharide-induced interleukin-8 gene expression in human granulocytes: transcriptional inhibition by interferon-gamma. Biochem. J. 310(Pt 3), 751-755. doi: 10.1042/bj3100751 
Cassatella, M. A., Meda, L., Bonora, S., Ceska, M., and Constantin, G. (1993). Interleukin 10 (IL-10) inhibits the release of proinflammatory cytokines from human polymorphonuclear leukocytes. Evidence for an autocrine role of tumor necrosis factor and IL-1 beta in mediating the production of IL- 8 triggered by lipopolysaccharide. J. Exp. Med. 178, 2207-2211. doi: 10.1084/jem.178.6.2207

Chechlinska, M., Kowalewska, M., and Nowak, R. (2010). Systemic inflammation as a confounding factor in cancer biomarker discovery and validation. Nat. Rev. Cancer 10, 2-3. doi: 10.1038/nrc2782

Cheng, S. S., Lai, J. J., Lukacs, N. W., and Kunkel, S. L. (2001). Granulocytemacrophage colony stimulating factor up-regulates CCR1 in human neutrophils. J. Immunol. 166, 1178-1184. doi: 10.4049/jimmunol.166.2.1178

Choi, J. C., Jung, J. W., Kwak, H. W., Song, J. H., Jeon, E. J., Shin, J. W., et al. (2008). Granulocyte macrophage-colony stimulating factor (GM-CSF) augments acute lung injury via its neutrophil priming effects. J. Korean Med. Sci. 23, 288-295. doi: $10.3346 / \mathrm{jkms} .2008 .23 .2 .288$

Cloutier, A., Ear, T., Blais-Charron, E., Dubois, C. M., and McDonald, P. P. (2007). Differential involvement of NF-kappaB and MAP kinase pathways in the generation of inflammatory cytokines by human neutrophils. J. Leukoc. Biol. 81, 567-577. doi: 10.1189/jlb.0806536

Cloutier, A., Guindi, C., Larivee, P., Dubois, C. M., Amrani, A., and McDonald, P. P. (2009). Inflammatory cytokine production by human neutrophils involves C/EBP transcription factors. J. Immunol. 182, 563-571. doi: 10.4049/jimmunol.182.1.563

Condliffe, A. M., Chilvers, E. R., Haslett, C., and Dransfield, I. (1996). Priming differentially regulates neutrophil adhesion molecule expression/function. Immunology 89, 105-111. doi: 10.1046/j.1365-2567.1996.d01-711.x

Condliffe, A. M., Kitchen, E., and Chilvers, E. R. (1998). Neutrophil priming: pathophysiological consequences and underlying mechanisms. Clin. Sci. 94, 461-471. doi: 10.1042/cs0940461

Cowburn, A. S., Cadwallader, K. A., Reed, B. J., Farahi, N., and Chilvers, E. R. (2002). Role of PI3-kinase-dependent Bad phosphorylation and altered transcription in cytokine-mediated neutrophil survival. Blood 100, 2607-2616. doi: 10.1182/blood-2001-11-0122

Dalli, J., Montero-Melendez, T., Norling, L. V., Yin, X., Hinds, C., Haskard, D., et al. (2013). Heterogeneity in neutrophil microparticles reveals distinct proteome and functional properties. Mol. Cell. Proteomics 12, 2205-2219. doi: 10.1074/mcp.M113.028589

Dapino, P., Dallegri, F., Ottonello, L., and Sacchetti, C. (1993). Induction of neutrophil respiratory burst by tumour necrosis factor-alpha; priming effect of solid-phase fibronectin and intervention of CD11b-CD18 integrins. Clin. Exp. Immunol. 94, 533-538. doi: 10.1111/j.1365-2249.1993.tb08230.x

DeLeo, F. R., Renee, J., McCormick, S., Nakamura, M., Apicella, M., Weiss, J. P., et al. (1998). Neutrophils exposed to bacterial lipopolysaccharide upregulate NADPH oxidase assembly. J. Clin. Invest. 101, 455-463. doi: 10.1172/JCI949

Della Bianca, V., Dusi, S., Nadalini, K. A., Donini, M., and Rossi, F. (1995). Role of 55- and 75-kDa TNF receptors in the potentiation of Fc-mediated phagocytosis in human neutrophils. Biochem. Biophys. Res. Commun. 214, 44-50. doi: 10.1006/bbrc.1995.2254

Demers, M., Krause, D. S., Schatzberg, D., Martinod, K., Voorhees, J. R., Fuchs, T. A., et al. (2012). Cancers predispose neutrophils to release extracellular DNA traps that contribute to cancer-associated thrombosis. Proc. Natl. Acad. Sci. U.S.A. 109, 13076-13081. doi: 10.1073/pnas.1200419109

Detmers, P. A., Lo, S. K., Olsen-Egbert, E., Walz, A., Baggiolini, M., and Cohn, Z. A. (1990). Neutrophil-activating protein 1/interleukin 8 stimulates the binding activity of the leukocyte adhesion receptor CD11b/CD18 on human neutrophils. J. Exp. Med. 171, 1155-1162. doi: 10.1084/jem.171.4.1155

Dewas, C., Dang, P. M., Gougerot-Pocidalo, M. A., and El-Benna, J. (2003). TNF-alpha induces a. phosphorylation of p47(phox) in human neutrophils: partial phosphorylation of p47phox is a common event of priming of human neutrophils by TNF-alpha and granulocyte-macrophage colony-stimulating factor. J. Immunol. 171, 4392-4398. doi: 10.4049/jimmunol.171.8.4392

Dianzani, C., Collino, M., Lombardi, G., Garbarino, G., and Fantozzi, R. (2003). Substance $\mathrm{P}$ increases neutrophil adhesion to human umbilical vein endothelial cells. Br. J. Pharmacol. 139, 1103-1110. doi: 10.1038/sj.bjp.0705344

Ding, Q., Quah, S. Y., and Tan, K. S. (2016). Secreted adenosine triphosphate from Aggregatibacter actinomycetemcomitans triggers chemokine response. Mol. Oral Microbiol. 31, 423-434. doi: 10.1111/omi.12143
DiPersio, J. F., Billing, P., Williams, R., and Gasson, J. C. (1988a). Human granulocyte-macrophage colony-stimulating factor and other cytokines prime human neutrophils for enhanced arachidonic acid release and leukotriene B4 synthesis. J. Immunol. 140, 4315-4322.

DiPersio, J. F., Naccache, P. H., Borgeat, P., Gasson, J. C., Nguyen, M. H., and McColl, S. R. (1988b). Characterization of the priming effects of human granulocyte-macrophage colony-stimulating factor on human neutrophil leukotriene synthesis. Prostaglandins 36, 673-691. doi: 10.1016/0090-6980(88)90013-5

DiScipio, R. G., Schraufstatter, I. U., Sikora, L., Zuraw, B. L., and Sriramarao, P. (2006). C5a mediates secretion and activation of matrix metalloproteinase 9 from human eosinophils and neutrophils. Int. Immunopharmacol. 6, 1109-1118. doi: 10.1016/j.intimp.2006.02.006

Doerfler, M. E., Weiss, J., Clark, J. D., and Elsbach, P. (1994). Bacterial lipopolysaccharide primes human neutrophils for enhanced release of arachidonic acid and causes phosphorylation of an $85-\mathrm{kD}$ cytosolic phospholipase A2. J. Clin. Invest. 93, 1583-1591. doi: 10.1172/JCI117138

Drost, E. M., and MacNee, W. (2002). Potential role of IL-8, plateletactivating factor and TNF-alpha in the sequestration of neutrophils in the lung: effects on neutrophil deformability, adhesion receptor expression, and chemotaxis. Eur. J. Immunol. 32, 393-403. doi: 10.1002/1521-4141(200202)32:2<393::AID-IMMU393>3.0.CO;2-5

Eken, C., Martin, P. J., Sadallah, S., Treves, S., Schaller, M., and Schifferli, J. A. (2010). Ectosomes released by polymorphonuclear neutrophils induce a MerTK-dependent anti-inflammatory pathway in macrophages. J. Biol. Chem. 285, 39914-39921. doi: 10.1074/jbc.M110.126748

El Azreq, M. A., Garceau, V., and Bourgoin, S. G. (2011). Cytohesin-1 regulates fMLF-mediated activation and functions of the beta 2 integrin Mac-1 in human neutrophils. J. Leukoc. Biol. 89, 823-836. doi: 10.1189/jlb.0410222

El-Benna, J., Dang, P. M., and Gougerot-Pocidalo, M. A. (2008). Priming of the neutrophil NADPH oxidase activation: role of $\mathrm{p} 47$ phox phosphorylation and NOX2 mobilization to the plasma membrane. Semin. Immunopathol. 30, 279-289. doi: 10.1007/s00281-008-0118-3

El-Benna, J., Faust, L. P., and Babior, B. M. (1994). The phosphorylation of the respiratory burst oxidase component p47phox during neutrophil activation. Phosphorylation of sites recognized by protein kinase $\mathrm{C}$ and by proline-directed kinases. J. Biol. Chem. 269, 23431-23436.

El-Benna, J., Han, J., Park, J. W., Schmid, E., Ulevitch, R. J., and Babior, B. M. (1996). Activation of p38 in stimulated human neutrophils: phosphorylation of the oxidase component p47phox by p38 and ERK but not by JNK. Arch. Biochem. Biophys. 334, 395-400. doi: 10.1006/abbi.1996.0470

El-Benna, J., Hurtado-Nedelec, M., Marzaioli, V., Marie, J. C., Gougerot-Pocidalo, M. A., and Dang, P. M. (2016). Priming of the neutrophil respiratory burst: role in host defense and inflammation. Immunol. Rev. 273, 180-193. doi: 10.1111/imr.12447

Ertel, W., Keel, M., Infanger, M., Ungethum, U., Steckholzer, U., and Trentz, O. (1998). Circulating mediators in serum of injured patients with septic complications inhibit neutrophil apoptosis through up-regulation of proteintyrosine phosphorylation. J. Trauma 44, 767-775; discussion: 775-766. doi: 10.1097/00005373-199805000-00005

Eun, J. C., Moore, E. E., Banerjee, A., Kelher, M. R., Khan, S. Y., Elzi, D. J., et al. (2011). Leukotriene b4 and its metabolites prime the neutrophil oxidase and induce proinflammatory activation of human pulmonary microvascular endothelial cells. Shock 35, 240-244. doi: 10.1097/SHK.0b013e3181faceb3

Fadini, G. P., Menegazzo, L., Rigato, M., Scattolini, V., Poncina, N., Bruttocao, A., et al. (2016). NETosis delays diabetic wound healing in mice and humans. Diabetes 65, 1061-1071. doi: 10.2337/db15-0863

Faldt, J., Dahlgren, C., Ridell, M., and Karlsson, A. (2001). Priming of human neutrophils by mycobacterial lipoarabinomannans: role of granule mobilisation. Microbes Infect. 3, 1101-1109. doi: 10.1016/S1286-4579(01)01470-8

Fan, J., and Malik, A. B. (2003). Toll-like receptor-4 (TLR4) signaling augments chemokine-induced neutrophil migration by modulating cell surface expression of chemokine receptors. Nat. Med. 9, 315-321. doi: 10.1038/nm832

Fernandez, M. C., Walters, J., and Marucha, P. (1996). Transcriptional and posttranscriptional regulation of GM-CSF-induced IL-1 beta gene expression in PMN. J. Leukoc. Biol. 59, 598-603. 
Feterowski, C., Weighardt, H., Emmanuilidis, K., Hartung, T., and Holzmann, B. (2001). Immune protection against septic peritonitis in endotoxin-primed mice is related to reduced neutrophil apoptosis. Eur. J. Immunol. 31, 1268-1277. doi: 10.1002/1521-4141(200104)31:4<1268::AID-IMMU1268>3.0.CO;2-C

Fietta, A., Francioli, C., and Gialdroni Grassi, G. (2000). Mycobacterial lipoarabinomannan affects human polymorphonuclear and mononuclear phagocyte functions differently. Haematologica $85,11-18$.

Finsterbusch, M., Voisin, M. B., Beyrau, M., Williams, T. J., and Nourshargh, S. (2014). Neutrophils recruited by chemoattractants in vivo induce microvascular plasma protein leakage through secretion of TNF. J. Exp. Med. 211, 1307-1314. doi: 10.1084 /jem.20132413

Fittschen, C., Sandhaus, R. A., Worthen, G. S., and Henson, P. M. (1988). Bacterial lipopolysaccharide enhances chemoattractant-induced elastase secretion by human neutrophils. J. Leukoc. Biol. 43, 547-556.

Flamand, N., Boudreault, S., Picard, S., Austin, M., Surette, M. E., Plante, H., et al. (2000). Adenosine, a potent natural suppressor of arachidonic acid release and leukotriene biosynthesis in human neutrophils. Am. J. Respir. Crit. Care Med. 161(2 Pt 2), S88-S94. doi: 10.1164/ajrccm.161.supplement_1.ltta-18

Forsberg, M., Löfgren, R., Zheng, L., and Stendahl, O. (2001). Tumour necrosis factor-alpha potentiates CR3-induced respiratory burst by activating p38 MAP kinase in human neutrophils. Immunology 103, 465-472. doi: 10.1046/j.1365-2567.2001.01270.x

Francois, S., El Benna, J., Dang, P. M., Pedruzzi, E., Gougerot-Pocidalo, M. A., and Elbim, C. (2005). Inhibition of neutrophil apoptosis by TLR agonists in whole blood: involvement of the phosphoinositide 3kinase/Akt and NF-kappaB signaling pathways, leading to increased levels of Mcl-1, A1, and phosphorylated Bad. J. Immunol. 174, 3633-3642. doi: $10.4049 /$ jimmunol.174.6.3633

Gasser, O., and Schifferli, J. A. (2004). Activated polymorphonuclear neutrophils disseminate anti-inflammatory microparticles by ectocytosis. Blood 104, 2543-2548. doi: 10.1182/blood-2004-01-0361

Gaudreault, E., and Gosselin, J. (2009). Leukotriene B4 potentiates CpG signaling for enhanced cytokine secretion by human leukocytes. J. Immunol. 183, 2650-2658. doi: 10.4049/jimmunol.0804135

Gaudreault, E., Paquet-Bouchard, C., Fiola, S., Le Bel, M., Lacerte, P., Shio, M. T., et al. (2012). TAK1 contributes to the enhanced responsiveness of LTB(4)treated neutrophils to Toll-like receptor ligands. Int. Immunol. 24, 693-704. doi: 10.1093/intimm/dxs074

Groemping, Y., Lapouge, K., Smerdon, S. J., and Rittinger, K. (2003). Molecular basis of phosphorylation-induced activation of the NADPH oxidase. Cell 113, 343-355. doi: 10.1016/S0092-8674(03)00314-3

Gyorgy, B., Szabo, T. G., Pasztoi, M., Pal, Z., Misjak, P., Aradi, B., et al. (2011). Membrane vesicles, current state-of-the-art: emerging role of extracellular vesicles. Cell. Mol. Life Sci. 68, 2667-2688. doi: 10.1007/s00018-0110689-3

Halpert, M. M., Thomas, K. A., King, R. G., and Justement, L. B. (2011). TLT2 potentiates neutrophil antibacterial activity and chemotaxis in response to G protein-coupled receptor-mediated signaling. J. Immunol. 187, 2346-2355. doi: $10.4049 /$ jimmunol.1100534

Hannah, S., Nadra, I., Dransfield, I., Pryde, J. G., Rossi, A. G., and Haslett, C. (1998). Constitutive neutrophil apoptosis in culture is modulated by cell density independently of beta2 integrin-mediated adhesion. FEBS Lett. 421, 141-146. doi: 10.1016/S0014-5793(97)01551-2

Harper, L., Cockwell, P., Adu, D., and Savage, C. O. (2001). Neutrophil priming and apoptosis in anti-neutrophil cytoplasmic autoantibody-associated vasculitis. Kidney Int. 59, 1729-1738. doi: 10.1046/j.1523-1755.2001.0590051729.x

Hayashi, F., Means, T. K., and Luster, A. D. (2003). Toll-like receptors stimulate human neutrophil function. Blood 102, 2660-2669. doi: 10.1182/blood-2003-04-1078

Hazeldine, J., Harris, P., Chapple, I. L., Grant, M., Greenwood, H., Livesey, A., et al. (2014). Impaired neutrophil extracellular trap formation: a novel defect in the innate immune system of aged individuals. Aging Cell 13, 690-698. doi: $10.1111 /$ acel.12222

Hong, Y., Eleftheriou, D., Hussain, A. A., Price-Kuehne, F. E., Savage, C. O., Jayne, D., et al. (2012). Anti-neutrophil cytoplasmic antibodies stimulate release of neutrophil microparticles. J. Am. Soc. Nephrol. 23, 49-62. doi: 10.1681/ASN.2011030298
Hu, M., Miller, E. J., Lin, X., and Simms, H. H. (2004). Transmigration across a lung epithelial monolayer delays apoptosis of polymorphonuclear leukocytes. Surgery 135, 87-98. doi: 10.1016/S0039-6060(03)00347-7

Humphreys, J. M., Hughes, V., and Edwards, S. W. (1989). Stimulation of protein synthesis in human neutrophils by gamma-interferon. Biochem. Pharmacol. 38, 1241-1246. doi: 10.1016/0006-2952(89)90329-8

Jablonska, E., Izycka, A., and Wawrusiewicz, N. (2002a). Effect of IL-18 on IL-1beta and sIL-1RII production by human neutrophils. Arch. Immunol. Ther. Exp. 50, 139-141.

Jablonska, E., Kiluk, M., Markiewicz, W., and Jablonski, J. (2002b). Priming effects of GM-CSF, IFN-gamma and TNF-alpha on human neutrophil inflammatory cytokine production. Melanoma Res. 12, 123-128. doi: 10.1097/00008390-200204000-00004

Jablonska, E., Piotrowski, L., Kiluk, M., Jablonski, J., Grabowska, Z., and Markiewicz, W. (2001). Effect of IL-15 on the secretion of IL-1beta, IL1 Ra and sIL-1RII by PMN from cancer patients. Cytokine 16, 173-177. doi: 10.1006/cyto.2001.0931

Jagels, M. A., Daffern, P. J., and Hugli, T. E. (2000). C3a and C5a enhance granulocyte adhesion to endothelial and epithelial cell monolayers: epithelial and endothelial priming is required for C3a-induced eosinophil adhesion. Immunopharmacology 46, 209-222. doi: 10.1016/S0162-3109(99)00178-2

Johnson, B. L. III, Kuethe, J. W., and Caldwell, C.C. (2014). Neutrophil derived microvesicles: emerging role of a key mediator to the immune response. Endocr. Metab. Immune Disord. Drug Targets 14, 210-217. doi: $10.2174 / 1871530314666140722083717$

Kannan, S. (2002). Amplification of extracellular nucleotide-induced leukocyte(s) degranulation by contingent autocrine and paracrine mode of leukotrienemediated chemokine receptor activation. Med. Hypotheses 59, 261-265. doi: 10.1016/S0306-9877(02)00213-X

Kannengiesser, C., Gerard, B., El Benna, J., Henri, D., Kroviarski, Y., CholletMartin, S., et al. (2008). Molecular epidemiology of chronic granulomatous disease in a series of 80 kindreds: identification of 31 novel mutations. Hum. Mutat. 29, E132-E149. doi: 10.1002/humu.20820

Kasorn, A., Alcaide, P., Jia, Y., Subramanian, K. K., Sarraj, B., Li, Y., et al. (2009). Focal adhesion kinase regulates pathogen-killing capability and life span of neutrophils via mediating both adhesion-dependent and -independent cellular signals. J. Immunol. 183, 1032-1043. doi: 10.4049/jimmunol.0802984

Kessenbrock, K., Krumbholz, M., Schonermarck, U., Back, W., Gross, W. L., Werb, Z., et al. (2009). Netting neutrophils in autoimmune small-vessel vasculitis. Nat. Med. 15, 623-625. doi: 10.1038/nm.1959

Khreiss, T., Jozsef, L., Chan, J. S., and Filep, J. G. (2004). Activation of extracellular signal-regulated kinase couples platelet-activating factor-induced adhesion and delayed apoptosis of human neutrophils. Cell. Signal. 16, 801-810. doi: 10.1016/j.cellsig.2003.12.005

Klebanoff, S. J., Olszowski, S., Van Voorhis, W. C., Ledbetter, J. A., Waltersdorph, A. M., and Schlechte, K. G. (1992). Effects of gamma-interferon on human neutrophils: protection from deterioration on storage. Blood 80, 225-234.

Klein, J. B., Buridi, A., Coxon, P. Y., Rane, M. J., Manning, T., Kettritz, R., et al. (2001). Role of extracellular signal-regulated kinase and phosphatidylinositol-3 kinase in chemoattractant and LPS delay of constitutive neutrophil apoptosis. Cell. Signal. 13, 335-343. doi: 10.1016/S0898-6568(01)00151-6

Klein, J. B., Rane, M. J., Scherzer, J. A., Coxon, P. Y., Kettritz, R., Mathiesen, J. M., et al. (2000). Granulocyte-macrophage colony-stimulating factor delays neutrophil constitutive apoptosis through phosphoinositide 3-kinase and extracellular signal-regulated kinase pathways. J. Immunol. 164, 4286-4291. doi: 10.4049/jimmunol.164.8.4286

Kletter, Y., Bleiberg, I., Golde, D. W., and Fabian, I. (1989). Antibody to Mol abrogates the increase in neutrophil phagocytosis and degranulation induced by granulocyte-macrophage colony-stimulating factor. Eur. J. Haematol. 43, 389-396. doi: 10.1111/j.1600-0609.1989.tb00325.x

Klimchenko, O., Di Stefano, A., Geoerger, B., Hamidi, S., Opolon, P., Robert, T., et al. (2011). Monocytic cells derived from human embryonic stem cells and fetal liver share common differentiation pathways and homeostatic functions. Blood 117, 3065-3075. doi: 10.1182/blood-2010-07-295246

Kowanko, I. C., Ferrante, A., Harvey, D. P., and Carman, K. L. (1991). Granulocyte-macrophage colony-stimulating factor augments neutrophil killing of Torulopsis glabrata and stimulates neutrophil 
respiratory burst and degranulation. Clin. Exp. Immunol. 83, 225-230. doi: 10.1111/j.1365-2249.1991.tb05619.x

Kulkarni, S., Woollard, K. J., Thomas, S., Oxley, D., and Jackson, S. P. (2007). Conversion of platelets from a proaggregatory to a proinflammatory adhesive phenotype: role of PAF in spatially regulating neutrophil adhesion and spreading. Blood 110, 1879-1886. doi: 10.1182/blood-2006-08-040980

Lamb, F. S., Hook, J. S., Hilkin, B. M., Huber, J. N., Volk, A. P., and Moreland, J. G. (2012). Endotoxin priming of neutrophils requires endocytosis and NADPH oxidase-dependent endosomal reactive oxygen species. J. Biol. Chem. 287, 12395-12404. doi: 10.1074/jbc.M111.306530

Lammermann, T., Afonso, P. V., Angermann, B. R., Wang, J. M., Kastenmuller, W., Parent, C. A., et al. (2013). Neutrophil swarms require LTB4 and integrins at sites of cell death in vivo. Nature, 498, 371-375. doi: 10.1038/nature12175

Lan, F., Yuan, B., Liu, T., Luo, X., Huang, P., Liu, Y., et al. (2016). Interleukin-33 facilitates neutrophil recruitment and bacterial clearance in $S$. aureus-caused peritonitis. Mol. Immunol. 72, 74-80. doi: 10.1016/j.molimm.2016.03.004

Le, H. T., Tran, V. G., Kim, W., Kim, J., Cho, H. R., and Kwon, B. (2012). IL33 priming regulates multiple steps of the neutrophil-mediated anti-Candida albicans response by modulating TLR and dectin-1 signals. J. Immunol. 189, 287-295. doi: 10.4049/jimmunol.1103564

Leslie, C. C. (2004). Regulation of arachidonic acid availability for eicosanoid production. Biochem. Cell Biol. 82, 1-17. doi: 10.1139/o03-080

Liles, W. C., Ledbetter, J. A., Waltersdorph, A. W., and Klebanoff, S. J. (1995), Cross-linking of CD18 primes human neutrophils for activation of the respiratory burst in response to specific stimuli: implications for adhesiondependent physiological responses in neutrophils. J. Leukoc. Biol. 58, 690-697.

Lindemann, A., Riedel, D., Oster, W., Meuer, S. C., Blohm, D., Mertelsmann, R. H., et al. (1988). Granulocyte/macrophage colony-stimulating factor induces interleukin 1 production by human polymorphonuclear neutrophils. J. Immunol. 140, 837-839.

Liu, J. J., Song, C. W., Yue, Y., Duan, C. G., Yang, J., He, T., et al. (2005). Quercetin inhibits LPS-induced delay in spontaneous apoptosis and activation of neutrophils. Inflamm. Res. 54, 500-507. doi: 10.1007/s00011-005-1385-2

Lominadze, G., Powell, D. W., Luerman, G. C., Link, A. J., Ward, R. A., and McLeish, K. R. (2005). Proteomic analysis of human neutrophil granules. Mol. Cell. Proteomics 4, 1503-1521. doi: 10.1074/mcp.M500143-MCP200

Lorincz, A. M., Schutte, M., Timar, C. I., Veres, D. S., Kittel, A., McLeish, K. R., et al. (2015). Functionally and morphologically distinct populations of extracellular vesicles produced by human neutrophilic granulocytes. J. Leukoc. Biol. 98, 583-589. doi: 10.1189/jlb.3VMA1014-514R

Luo, M., Jones, S. M., Peters-Golden, M., and Brock, T. G. (2003). Nuclear localization of 5-lipoxygenase as a determinant of leukotriene B4 synthetic capacity. Proc. Natl. Acad. Sci. U.S.A. 100, 12165-12170. doi: $10.1073 /$ pnas. 2133253100

Makni-Maalej, K., Boussetta, T., Hurtado-Nedelec, M., Belambri, S. A., GougerotPocidalo, M. A., and El-Benna, J. (2012). The TLR7/8 agonist CL097 primes Nformyl-methionyl-leucyl-phenylalanine-stimulated NADPH oxidase activation in human neutrophils: critical role of p47phox phosphorylation and the proline isomerase Pin1. J. Immunol. 189, 4657-4665. doi: 10.4049/jimmunol.12 01007

Makni-Maalej, K., Marzaioli, V., Boussetta, T., Belambri, S. A., Gougerot-Pocidalo, M. A., Hurtado-Nedelec, M., et al. (2015). TLR8, but not TLR7, induces the priming of the NADPH oxidase activation in human neutrophils. J. Leukoc. Biol. 97, 1081-1087. doi: 10.1189/jlb.2A1214-623R

Mancuso, P., Nana-Sinkam, P., and Peters-Golden, M. (2001). Leukotriene B4 augments neutrophil phagocytosis of Klebsiella pneumoniae. Infect. Immun. 69, 2011-2016. doi: 10.1128/IAI.69.4.2011-2016.2001

Marasco, W. A., Showell, H. J., and Becker, E. L. (1981). Substance P binds to the formylpeptide chemotaxis receptor on the rabbit neutrophil. Biochem. Biophys. Res. Commun. 99, 1065-1072. doi: 10.1016/0006-291X(81) 90727-0

Marucha, P. T., Zeff, R. A., and Kreutzer, D. L. (1991). Cytokine-induced IL-1 beta gene expression in the human polymorphonuclear leukocyte: transcriptional and post-transcriptional regulation by tumor necrosis factor and IL-1. J. Immunol. 147, 2603-2608.

Mastroianni, C. M., d'Ettorre, G., Forcina, G., Lichtner, M., Mengoni, F., D’Agostino, C., et al. (2000). Interleukin-15 enhances neutrophil functional activity in patients with human immunodeficiency virus infection. Blood 96, 1979-1984.

Mayadas, T. N., and Cullere, X. (2005). Neutrophil beta2 integrins: moderators of life or death decisions. Trends Immunol. 26, 388-395. doi: 10.1016/j.it.2005.05.002

Mayer, T. Z., Simard, F. A., Cloutier, A., Vardhan, H., Dubois, C. M., and McDonald, P. P. (2013). The p38-MSK1 signaling cascade influences cytokine production through CREB and C/EBP factors in human neutrophils. J. Immunol. 191, 4299-4307. doi: 10.4049/jimmunol.1301117

McGettrick, H. M., Lord, J. M., Wang, K. Q., Rainger, G. E., Buckley, C. D., and Nash, G. B. (2006). Chemokine- and adhesion-dependent survival of neutrophils after transmigration through cytokine-stimulated endothelium. J. Leukoc. Biol. 79, 779-788. doi: 10.1189/jlb.0605350

McLeish, K. R., Klein, J. B., Lederer, E. D., Head, K. Z., and Ward, R. A. (1996). Azotemia, TNF alpha, and LPS prime the human neutrophil oxidative burst by distinct mechanisms. Kidney Int. 50, 407-416.

McLeish, K. R., Knall, C., Ward, R. A., Gerwins, P., Coxon, P. Y., Klein, J. B., et al. (1998). Activation of mitogen-activated protein kinase cascades during priming of human neutrophils by TNF-alpha and GM-CSF. J. Leukoc. Biol. 64, 537-545.

McLeish, K. R., Merchant, M. L., Creed, T. M., Tandon, S., Barati, M. T., Uriarte, S. M., et al. (2017). Frontline Science: tumor necrosis factor- $\alpha$ stimulation and priming of human neutrophil granule exocytosis. J. Leukoc. Biol. doi: 10.1189/jlb.3HI0716-293RR. [Epub ahead of print].

McLeish, K. R., Uriarte, S. M., Tandon, S., Creed, T. M., Le, J., and Ward, R. A. (2013). Exocytosis of neutrophil granule subsets and activation of prolyl isomerase 1 are required for respiratory burst priming. J. Innate Immun. 5, 277-289. doi: 10.1159/000345992

Melby, K., Midtvedt, T., and Degre, M. (1982). Effect of human leukocyte interferon on phagocytic activity of polymorphonuclear leukocytes. Acta Pathol. Microbiol. Immunol. Scand. B 90, 181-184. doi: 10.1111/j.1699-0463.1982.tb00102.x

Meshki, J., Tuluc, F., Bredetean, O., Ding, Z., and Kunapuli, S. P. (2004) Molecular mechanism of nucleotide-induced primary granule release in human neutrophils: role for the P2Y2 receptor. Am. J. Physiol. Cell Physiol. 286, C264-C271. doi: 10.1152/ajpcell.00287.2003

Mesri, M., and Altieri, D. C. (1998). Endothelial cell activation by leukocyte microparticles. J. Immunol. 161, 4382-4387.

Mocsai, A., Ligeti, E., Lowell, C. A., and Berton, G. (1999). Adhesion-dependent degranulation of neutrophils requires the Src family kinases Fgr and Hck. J. Immunol. 162, 1120-1126.

Montecucco, F., Steffens, S., Burger, F., Da Costa, A., Bianchi, G., Bertolotto, M., et al. (2008). Tumor necrosis factor-alpha (TNF-alpha) induces integrin CD11b/CD18 (Mac-1) up-regulation and migration to the CC chemokine CCL3 (MIP-1alpha) on human neutrophils through defined signalling pathways. Cell. Signal. 20, 557-568. doi: 10.1016/j.cellsig.2007.11.008

Moreland, J. G., Davis, A. P., Matsuda, J. J., Hook, J. S., Bailey, G., Nauseef, W. M., et al. (2007). Endotoxin priming of neutrophils requires NADPH oxidasegenerated oxidants and is regulated by the anion transporter ClC-3. J. Biol. Chem. 282, 33958-33967. doi: 10.1074/jbc.M705289200

Morris, A. C., Brittan, M., Wilkinson, T. S., McAuley, D. F., Antonelli, J., McCulloch, C., et al. (2011). C5a-mediated neutrophil dysfunction is RhoAdependent and predicts infection in critically ill patients. Blood 117, 5178-5188. doi: 10.1182/blood-2010-08-304667

Moutsopoulos, N. M., Konkel, J., Sarmadi, M., Eskan, M. A., Wild, T., Dutzan, N., et al. (2014). Defective neutrophil recruitment in leukocyte adhesion deficiency type I disease causes local IL-17-driven inflammatory bone loss. Sci. Transl. Med. 6, 229ra40. doi: 10.1126/scitranslmed.3007696

Murray, J., Barbara, J. A., Dunkley, S. A., Lopez, A. F., Van Ostade, X., Condliffe, A. M., et al. (1997). Regulation of neutrophil apoptosis by tumor necrosis factoralpha: requirement for TNFR55 and TNFR75 for induction of apoptosis in vitro. Blood 90, 2772-2783.

Musso, T., Calosso, L., Zucca, M., Millesimo, M., Puliti, M., Bulfone-Paus, S., et al. (1998). Interleukin-15 activates proinflammatory and antimicrobial functions in polymorphonuclear cells. Infect. Immun. 66, 2640-2647.

Naegele, M., Tillack, K., Reinhardt, S., Schippling, S., Martin, R., and Sospedra, M. (2012). Neutrophils in multiple sclerosis are characterized by a primed phenotype. J. Neuroimmunol. 242, 60-71. doi: 10.1016/j.jneuroim.2011.11.009 
Nathan, C. (2006). Neutrophils and immunity: challenges and opportunities. Nat. Rev. Immunol. 6, 173-182. doi: 10.1038/nri1785

Nauseef, W. M., and Borregaard, N. (2014). Neutrophils at work. Nat. Immunol. 15, 602-611. doi: 10.1038/ni.2921

Nemeth, T., and Mocsai, A. (2016). Feedback amplification of neutrophil function. Trends Immunol. 37, 412-424. doi: 10.1016/j.it.2016.04.002

Nolan, B., Collette, H., Baker, S., Duffy, A., De, M., Miller, C., et al. (2000). Inhibition of neutrophil apoptosis after severe trauma is NFkappa $\beta$ dependent. J. Trauma 48, 599-604; discussion: 604-595.

O'Flaherty, J. T., Showell, H. J., Becker, E. L., and Ward, P. A. (1979). Neutrophil aggregation and degranulation. Effect of arachidonic acid. Am. J. Pathol. 95, 433-444.

Ogura, H., Tanaka, H., Koh, T., Hashiguchi, N., Kuwagata, Y., Hosotsubo, H., et al. (1999). Priming, second-hit priming, and apoptosis in leukocytes from trauma patients. J. Trauma 46, 774-781; discussion: 781-773. doi: 10.1097/00005373-199905000-00004

Palmantier, R., Surette, M. E., Sanchez, A., Braquet, P., and Borgeat, P. (1994). Priming for the synthesis of 5-lipoxygenase products in human blood ex vivo by human granulocyte-macrophage colony-stimulating factor and tumor necrosis factor-alpha. Lab. Invest. 70, 696-704.

Paulsson, J. M., Jacobson, S. H., and Lundahl, J. (2010). Neutrophil activation during transmigration in vivo and in vitro A translational study using the skin chamber model. J. Immunol. Methods 361, 82-88. doi: 10.1016/j.jim.2010.07.015

Perianayagam, M. C., Balakrishnan, V. S., King, A. J., Pereira, B. J., and Jaber, B. L. (2002). C5a delays apoptosis of human neutrophils by a phosphatidylinositol 3-kinase-signaling pathway. Kidney Int. 61, 456-463. doi: 10.1046/j.1523-1755.2002.00139.x

Perianin, A., Snyderman, R., and Malfroy, B. (1989). Substance P primes human neutrophil activation: a mechanism for neurological regulation of inflammation. Biochem. Biophys. Res. Commun. 161, 520-524. doi: 10.1016/0006-291X(89)92630-2

Perussia, B., Kobayashi, M., Rossi, M. E., Anegon, I., and Trinchieri, G. (1987). Immune interferon enhances functional properties of human granulocytes: role of $\mathrm{FC}$ receptors and effect of lymphotoxin, tumor necrosis factor, and granulocyte-macrophage colony-stimulating factor. J. Immunol. 138, 765-774.

Pliyev, B. K., Kalintseva, M. V., Abdulaeva, S. V., Yarygin, K. N., and Savchenko, V. G. (2014). Neutrophil microparticles modulate cytokine production by natural killer cells. Cytokine 65, 126-129. doi: 10.1016/j.cyto.2013.11.010

Pluskota, E., Woody, N. M., Szpak, D., Ballantyne, C. M., Soloviev, D. A., Simon, D. I., et al. (2008). Expression, activation, and function of integrin alphaMbeta2 (Mac-1) on neutrophil-derived microparticles. Blood 112, 2327-2335. doi: 10.1182/blood-2007-12-127183

Podaza, E., Sabbione, F., Risnik, D., Borge, M., Almejun, M. B., Colado, A., et al. (2016). Neutrophils from chronic lymphocytic leukemia patients exhibit an increased capacity to release extracellular traps (NETs). Cancer Immunol. Immunother. 66, 77-89. doi: 10.1007/s00262-016-1921-7

Potera, R. M., Jensen, M. J., Hilkin, B. M., South, G. K., Hook, J. S., Gross, E. A., et al. (2016). Neutrophil azurophilic granule exocytosis is primed by TNFalpha and partially regulated by NADPH oxidase. Innate Immun. 22, 635-646. doi: $10.1177 / 1753425916668980$

Rainard, P., Riollet, C., Poutrel, B., and Paape, M. J. (2000). Phagocytosis and killing of Staphylococcus aureus by bovine neutrophils after priming by tumor necrosis factor-alpha and the des-arginine derivative of C5a. Am. J. Vet. Res. 61, 951-959. doi: 10.2460/ajvr.2000.61.951

Ramadass, M., Johnson, J. L., and Catz, S. D. (2017). Rab27a regulates GM-CSFdependent priming of neutrophil exocytosis. J. Leukoc. Biol. 101, 693-702. doi: 10.1189/jlb.3AB0416-189RR

Richardson, M. D., and Patel, M. (1995). Stimulation of neutrophil phagocytosis of Aspergillus fumigatus conidia by interleukin-8 and Nformylmethionyl-leucylphenylalanine. J. Med. Vet. Mycol. 33, 99-104. doi: 10.1080/02681219580000221

Roberge, C. J., McColl, S. R., Larochelle, B., and Gosselin, J. (1998). Granulocytemacrophage colony-stimulating factor enhances EBV-induced synthesis of chemotactic factors in human neutrophils. J. Immunol. 160, 2442-2448.

Rørvig, S., Øtergaard, O., Heegaard, N. H., and Borregaard, N. (2013). Proteome profiling of human neutrophil granule subsets, secretory vesicles, and cell membrane: correlation with transcriptome profiling of neutrophil precursors. J. Leukoc. Biol. 94, 711-721. doi: 10.1189/jlb.1212619

Rosales, C., and Brown, E. J. (1991). Two mechanisms for IgG Fc-receptormediated phagocytosis by human neutrophils. J. Immunol. 146, 3937-3944.

Sabroe, I., Prince, L. R., Jones, E. C., Horsburgh, M. J., Foster, S. J., Vogel, S. N., et al. (2003). Selective roles for Toll-like receptor (TLR)2 and TLR4 in the regulation of neutrophil activation and life span. J. Immunol. 170, 5268-5275. doi: 10.4049/jimmunol.170.10.5268

Salamone, G. V., Petracca, Y., Fuxman Bass, J. I., Rumbo, M., Nahmod, K. A. Gabelloni, M. L., et al. (2010). Flagellin delays spontaneous human neutrophil apoptosis. Lab. Invest. 90, 1049-1059. doi: 10.1038/labinvest.2010.77

Schatz-Munding, M., and Ullrich, V. (1992). Priming of human polymorphonuclear leukocytes with granulocyte-macrophage colony-stimulating factor involves protein kinase $\mathrm{C}$ rather than enhanced calcium mobilisation. Eur. J. Biochem. 204, 705-712. doi: 10.1111/j.1432-1033.1992.tb16685.x

Seeds, M. C., Jones, D. F., Chilton, F. H., and Bass, D. A. (1998). Secretory and cytosolic phospholipases A2 are activated during TNF priming of human neutrophils. Biochim. Biophys. Acta 1389, 273-284. doi: 10.1016/S0005-2760(97)00151-3

Sengelov, H., Follin, P., Kjeldsen, L., Lollike, K., Dahlgren, C., and Borregaard, N. (1995). Mobilization of granules and secretory vesicles during in vivo exudation of human neutrophils. J. Immunol. 154, 4157-4165.

Sengelov, H., Kjeldsen, L., and Borregaard, N. (1993). Control of exocytosis in early neutrophil activation. J. Immunol. 150, 1535-1543.

Shalit, M., Dabiri, G. A., and Southwick, F. S. (1987). Platelet-activating factor both stimulates and "primes" human polymorphonuclear leukocyte actin filament assembly. Blood 70, 1921-1927.

Sheppard, F. R., Kelher, M. R., Moore, E. E., McLaughlin, N. J., Banerjee, A., and Silliman, C. C. (2005). Structural organization of the neutrophil NADPH oxidase: phosphorylation and translocation during priming and activation. $J$. Leukoc. Biol. 78, 1025-1042. doi: 10.1189/jlb.0804442

Sorensen, O. E., and Borregaard, N. (2016). Neutrophil extracellular traps - the dark side of neutrophils. J. Clin. Invest. 126, 1612-1620. doi: 10.1172/JCI84538

Stanislawski, L., Huu, T. P., and Perianin, A. (1990). Priming effect of fibronectin on respiratory burst of human neutrophils induced by formyl peptides and platelet-activating factor. Inflammation 14, 523-530. doi: 10.1007/BF00914273

Steadman, R., Petersen, M. M., and Williams, J. D. (1996). CD11b/CD18dependent stimulation of leukotriene B4 synthesis by human neutrophils (PMN) is synergistically enhanced by tumour necrosis factor alpha and low dose diacylglycerol. Int. J. Biochem. Cell Biol. 28, 771-776. doi: 10.1016/1357-2725(96)00015-5

Summers, C., Rankin, S. M., Condliffe, A. M., Singh, N., Peters, A. M., and Chilvers, E. R. (2010). Neutrophil kinetics in health and disease. Trends Immunol. 31, 318-324. doi: 10.1016/j.it.2010.05.006

Surette, M. E., Dallaire, N., Jean, N., Picard, S., and Borgeat, P. (1998). Mechanisms of the priming effect of lipopolysaccharides on the biosynthesis of leukotriene B4 in chemotactic peptide-stimulated human neutrophils. FASEB J. 12, 1521-1531.

Surette, M. E., Palmantier, R., Gosselin, J., and Borgeat, P. (1993). Lipopolysaccharides prime whole human blood and isolated neutrophils for the increased synthesis of 5-lipoxygenase products by enhancing arachidonic acid availability: involvement of the CD14 antigen. J. Exp. Med. 178, 1347-1355. doi: $10.1084 /$ jem.178.4.1347

Swain, S. D., Rohn, T. T., and Quinn, M. T. (2002). Neutrophil priming in host defense: role of oxidants as priming agents. Antioxid. Redox Signal. 4, 69-83. doi: $10.1089 / 152308602753625870$

Timar, C. I., Lorincz, A. M., Csepanyi-Komi, R., Valyi-Nagy, A., Nagy, G., Buzas, E. I., et al. (2013a). Antibacterial effect of microvesicles released from human neutrophilic granulocytes. Blood 121, 510-518. doi: 10.1182/blood-2012-05-431114

Timar, C. I., Lorincz, A. M., and Ligeti, E. (2013b). Changing world of neutrophils. Pflugers Arch. 465, 1521-1533. doi: 10.1007/s00424-013-1285-1

Tsuboi, N., Ernandez, T., Li, X., Nishi, H., Cullere, X., Mekala, D., et al. (2011). Regulation of human neutrophil Fcgamma receptor IIa by C5a receptor promotes inflammatory arthritis in mice. Arthritis Rheum. 63, 467-478. doi: $10.1002 /$ art.30141 
Uriarte, S. M., Rane, M. J., Luerman, G. C., Barati, M. T., Ward, R. A., Nauseef, W. M., et al. (2011). Granule exocytosis contributes to priming and activation of the human neutrophil respiratory burst. J. Immunol. 187, 391-400. doi: 10.4049/jimmunol.1003112

van de Vijver, E., Maddalena, A., Sanal, O., Holland, S. M., Uzel, G., Madkaikar, M., et al. (2012). Hematologically important mutations: leukocyte adhesion deficiency (first update). Blood Cells Mol. Dis. 48, 53-61. doi: 10.1016/j.bcmd.2011.10.004

Volk, A. P., Barber, B. M., Goss, K. L., Ruff, J. G., Heise, C. K., Hook, J. S., et al. (2011). Priming of neutrophils and differentiated PLB-985 cells by pathophysiological concentrations of TNF-alpha is partially oxygen dependent. J. Innate Immun. 3, 298-314. doi: 10.1159/000321439

Ward, R. A., Nakamura, M., and McLeish, K. R. (2000). Priming of the neutrophil respiratory burst involves p38 mitogen-activated protein kinase-dependent exocytosis of flavocytochrome b558-containing granules. J. Biol. Chem. 275, 36713-36719. doi: 10.1074/jbc.M003017200

Whitmore, L. C., Hook, J. S., Philiph, A. R., Hilkin, B. M., Bing, X., Ahn, C., et al. (2016). A common genetic variant in TLR1 enhances human neutrophil priming and impacts length of intensive care stay in pediatric sepsis. J. Immunol. 196, 1376-1386. doi: 10.4049/jimmunol.1500856

Wozniak, A., McLennan, G., Betts, W. H., Murphy, G. A., and Scicchitano, R. (1989). Activation of human neutrophils by substance P: effect on FMLPstimulated oxidative and arachidonic acid metabolism and on antibodydependent cell-mediated cytotoxicity. Immunology 68, 359-364.

Wright, H. L., Cross, A. L., Edwards, S. W., and Moots, R. J. (2014). Effects of IL-6 and IL-6 blockade on neutrophil function in vitro and in vivo. Rheumatology 53, 1321-1331. doi: 10.1093/rheumatology/keu035

Wright, H. L., Thomas, H. B., Moots, R. J., and Edwards, S. W. (2013). RNA-seq reveals activation of both common and cytokine-specific pathways following neutrophil priming. PLOS ONE 8:e58598. doi: 10.1371/journal.pone.00 58598

Wyman, T. H., Dinarello, C. A., Banerjee, A., Gamboni-Robertson, F., Hiester, A. A., England, K. M., et al. (2002). Physiological levels of interleukin-18 stimulate multiple neutrophil functions through p38 MAP kinase activation. J. Leukoc. Biol. 72, 401-409.
$\mathrm{Xu}, \mathrm{X}$., and Hakansson, L. (2002). Degranulation of primary and secondary granules in adherent human neutrophils. Scand. J. Immunol. 55, 178-188. doi: 10.1046/j.1365-3083.2002.01041.X

Yao, Y., Matsushima, H., Ohtola, J. A., Geng, S., Lu, R., and Takashima, A. (2015). Neutrophil priming occurs in a sequential manner and can be visualized in living animals by monitoring IL-1beta promoter activation. J. Immunol. 194, 1211-1224. doi: 10.4049/jimmunol.1402018

Yousefi, S., Mihalache, C., Kozlowski, E., Schmid, I., and Simon, H. U. (2009). Viable neutrophils release mitochondrial DNA to form neutrophil extracellular traps. Cell Death Differ. 16, 1438-1444. doi: 10.1038/cdd.2009.96

Yuo, A., Kitagawa, S., Ohsaka, A., Saito, M., and Takaku, F. (1990). Stimulation and priming of human neutrophils by granulocyte colony-stimulating factor and granulocyte-macrophage colony-stimulating factor: qualitative and quantitative differences. Biochem. Biophys. Res. Commun. 171, 491-497. doi: 10.1016/0006-291X(90)91420-W

Zallen, G., Moore, E. E., Johnson, J. L., Tamura, D. Y., Aiboshi, J., Biffl, W. L., et al. (1999). Circulating postinjury neutrophils are primed for the release of proinflammatory cytokines. J. Trauma 46, 42-48. doi: 10.1097/00005373-199901000-00007

Zarini, S., Gijon, M. A., Folco, G., and Murphy, R. C. (2006). Effect of arachidonic acid reacylation on leukotriene biosynthesis in human neutrophils stimulated with granulocyte-macrophage colony-stimulating factor and formyl-methionyl-leucyl-phenylalanine. J. Biol. Chem. 281, 10134-10142. doi: 10.1074/jbc.M510783200

Conflict of Interest Statement: The authors declare that the research was conducted in the absence of any commercial or financial relationships that could be construed as a potential conflict of interest.

Copyright (c) 2017 Miralda, Uriarte and McLeish. This is an open-access article distributed under the terms of the Creative Commons Attribution License (CC BY). The use, distribution or reproduction in other forums is permitted, provided the original author(s) or licensor are credited and that the original publication in this journal is cited, in accordance with accepted academic practice. No use, distribution or reproduction is permitted which does not comply with these terms. 